\title{
JOHN GERARD WITTHOFT
}

\author{
$1921-1993$
}

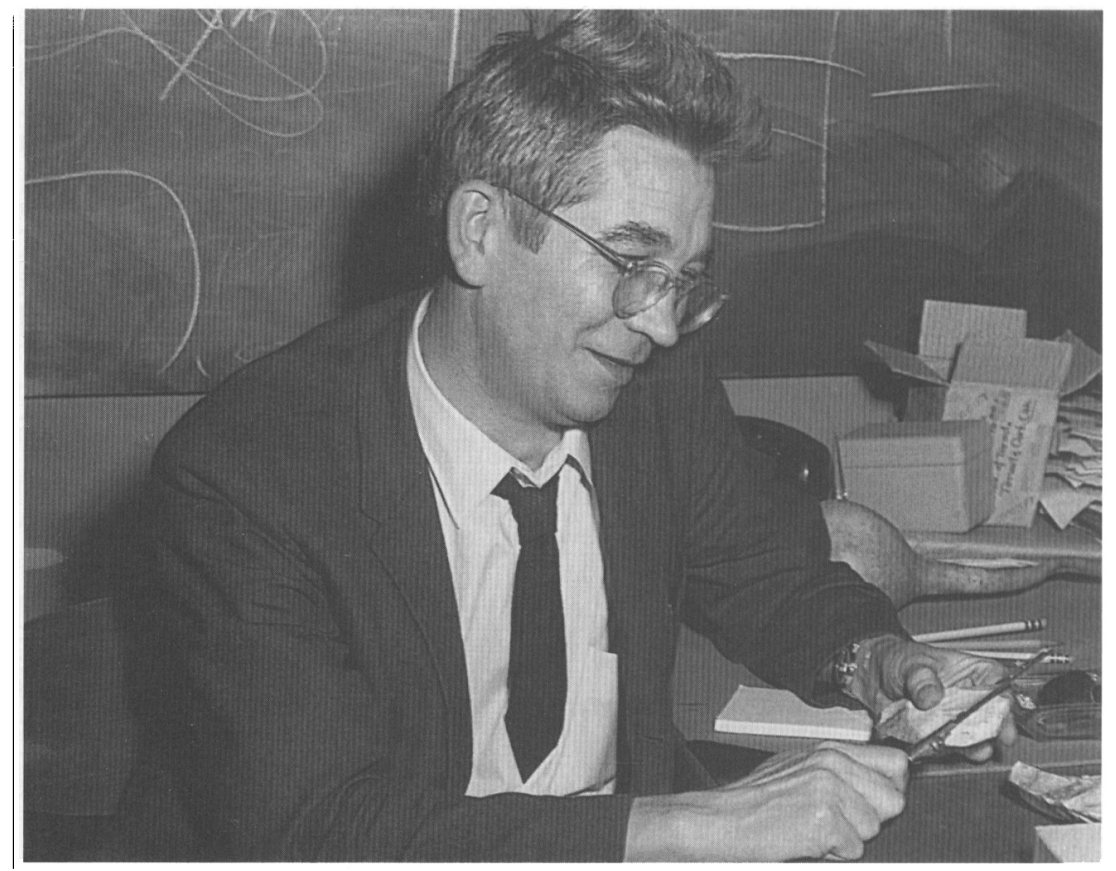

7 o be singularly admired by nonprofessional archaeologists, extraordinarily popular with university students as a gifted and generous teacher, and accepted by his peers in archaeology as a scholar and authority, were achievements uniquely associated with John Witthoft.

Having developed an encyclopedic mind and memory, John lectured day after day at the Department of Anthropology at the University of Pennsylvania from 1966 until his retirement in 1986 as emeritus associate professor - without notes, citing names, dates, complete references, and an infinity of anecdotal accounts, speaking clearly, concisely, and in paragraphs (as his lecture recorders discovered), never impaired by the pellet of snuff he always retained in his mouth. A quiet gentle man who knew adversity early and often, he never let circumstances dull his zest for knowledge. John lived simply, avoided pretense, relying on Quaker values and guiding principles. His pony tail, graying hair, snuff, indifferent dress, and grand disdain of fashion never interfered with his willingness to share what he knew in order to help others.

John's field of research and investigation was primarily Native American ethnology and prehistory, but it extended into the European frontier and its material culture. He spoke and lectured more extensively than he wrote, but he did manage to produce three volumes and more than 100 articles for schol-

American Antiquity, 61(2), 1996, pp. 279-284.

Copyright $\mathcal{C}$ by the Society for American Archaeology 
arly journals. The volumes he did not write were in his ostensibly extemporaneous lectures, which he planned and researched carefully before he spoke.

Born October 4, 1921, in Oneonta, New York, the oldest of the four children of Henry John and Janet Lucey Witthoft, John was an avid reader at five, and at age six he was dismissed from a Catholic elementary school for arguing with the nuns about evolution. Shortly thereafter he was diagnosed as having scarlet fever and quarantined - for the sake of the family and community - in the attic. Here he was isolated for six months, communicating through a closed door that opened only to give access to trays of food. During his confinement John read western stories avidly. When he emerged, he was told that his affliction was due to his defiance of the nuns, and he forsook the church thereafter. The disease left him with tremors in one hand and eye damage that troubled him the rest of his life.

At 13, after many moves and many schools, he was on his own, working for painters, plumbers, and gardeners after school, paying his room and board at home-having been told by his mother that no one who did not accept the faith could expect to be fed and housed by her. Thus John's earnings helped to support his two sisters and brothers as well.

By this time he had already enjoyed his first year as a member of the Van Epp-Hartley Chapter of the New York Archaeological Society, where he was inspired by Percy Van Epp, one of the chapter founders, to turn to archaeology. It was not until he was 14 and had his eyes examined that he bought himself glasses that revealed a new world of vision his extreme nearsightedness had denied him - most importantly, stratigraphy.

At 15 John found his ideal job working at Albany in the used bookstore of Samuel Lockridge where he devoured rare books and manuscripts, becoming a confirmed bibliophile and philatelist. His formal education, after his valedictory address at his high school graduation, consisted of a bachelor's in biology and English from the State University of New York at Albany in 1944, and a master's in anthropology from the University of Pennsylvania in 1946. His choice of Penn was prompted by his admiration for the ethnographic fieldwork of his mentor there, Frank Speck. He continued graduate study at the University of Michigan as an Eli Lilly Fellow in archaeology, but did not pursue a doctorate.

John's teaching skills were employed first when he was a student-instructor at New York State in 1942. They were called on again from 1945 to 1946 when he served as instructor with the Army Specialized Training Program in Japanese language and culture at the University of Pennsylvania, while he pursued his master's. He was a teaching assistant to Leslie White, and studied with James Griffin and Micha Titiev while he was at the University of Michigan.

John was one of the last students of Frank Gouldsmith Speck, who developed the Department of Anthropology at Penn, which he chaired for many years. Speck was a legendary participant-observer of surviving American life. Both he and Witthoft had grown up in contact with Native American people - in Witthoft's case in upstate New York, and for Speck in Connecticut with one of the last surviving speakers of the Mohegan language, who was his foster mother for most of his childhood. Both men had a deep cognition of aboriginal life and culture, and a casual disregard for the fashions and pretenses of their academic and social peers. Both had a profound interest in the natural history of the landscape in which cultures were nurtured, past and present. This interest would veer in at least one amusing way.

Speck felt that the turtles harbored by the Philadelphia Zoo were grossly neglected-a concern eventually shared by Witthoft. One night the two of them invaded the zoo and loaded the slighted turtles onto a truck, which they drove to an inviting pond in Swarthmore, Pennsylvania. Here they liberated their cargo into a more congenial environment. The police, however, managed to trace the truck to the two turtlenappers, who, under threat of having to reimburse the zoo $\$ 600$ for the missing turtles, were obliged to muster them again for the return trip to the zoo. Subsequently, the zoo director proffered a receipt for the turtles and thanked them for including two additional specimens, which had apparently been neighborhood turtles seduced by the newcomers. Speck had the satisfaction of knowing the escapade seemed to have worked to some degree: he observed that the zoo greatly upgraded the turtle habitat following the incident. 
From 1948 to 1966 Witthoft worked at the Pennsylvania State Museum in Harrisburg while serving as state archaeologist, chief curator, and state anthropologist. During this time he worked with children in the Police Athletic League and helped produce a children's television program using the museum's extensive archaeological and ethnological resources. He was fast becoming a professional guru to every chapter of the Society for Pennsylvania Archaeology, and was responsible for persuading-with patience, gentleness, and generous participation-many an "avocational archaeologist" to do careful fieldwork, keep reliable records, and cooperate with professionals. Although he did not drive a car after his early youth, and never owned one, John could be relied on to appear at digs and discoveries of significance as adviser and friend, and as the guest of whatever group was at work. Often a speaker at various meetings, he never asked a fee. In this way he saved and ensured the recording of numerous important sites, and was responsible for excavating the stratified dry rock shelter called Sheeprock, in Huntington County northwest of Harrisburg, as well as for analyzing Paleoindian materials from the Shoop site in Dauphin County. Some of Witthoft's analyses here have been challenged; this did not dismay him, since what did not meet the test of time at least evoked more research. More detailed notes on Witthoft's Pennsylvania fieldwork are in Barry C. Kent's A Tribute to John Witthoft in the Pennsylvania Archaeologist 64 (March 1994), pp. 1 and 2.

Many reports of Witthoft's field investigations remain unpublished, notably those site tests performed in anticipation of constructions. One amusing instance involved an impolitic investigation, with military historian and archaeologist J. Duncan Campbell, of Washington Square, Philadelphia, in 1956. John was prevailed on to help locate an "Unknown Soldier of the American Revolution" among the several thousand pauper, plague victim, and soldier burials of the eighteenth century. Then state archaeologist in a Republican administration at odds with the Democrative Reform administration of Philadelphia, Witthoft took the job only under strict anonymity.

Just as the musket ball-struck solider was located, the "media" invaded the site, and John fled, leaving Campbell to deliver the bones, which were duly reburied with honors by the eternel flame memorial. The story would have remained untold had John not related it to me for inclusion in The Buried Past: An Archaeological History of Philadelpha (1992), of which I was coauthor.

John Witthoft joined the faculty of the Department of Anthropology at the University of Pennsylvania in 1966, from which he retired in 1986 as associate professor emeritus. During his teaching career at Penn he was able to continue field research among Eastern Cherokee, Seneca, Cayuga, Delaware, and Cataba in the Atlantic region, and in the West, the Hopi and Paiute. Always interested in archaeology, he frequently traveled to sites of particular significance throughout the country, including colonial and federal sites. At Penn John served as mentor and archaeological consultant to many, and supervised a number of doctoral dissertations. When a painful back ended his field activity, he directed his research to ethnographic fieldwork with the Eastern Cherokee and Iroquois, and continued his work in ethnography and historical archaeology. His papers on Indian hunting practices, on colonial fur trade, and on guns and the typology of gunflints are among the classic literature on these subjects (albeit he disliked firearms). He greatly preferred to work on the ethnohistory of the Iroquois, Shawnee, Conestoga, and Lenape, and to continue his research on Cherokee ethnobotany. Furthermore, his ability to identify and analyze archaeological sites in the Northeast was as widely known as his ability to put ideas from far-reaching sources together for new constructs.

John Witthoft married Jean Fischer in 1945; they had three children, Tsani ("John" in Cherokee), Jean, and Maria; after a divorce, John raised the two girls while Tsani remained with Jean. In 1966 John married Alice Frances Eyman, keeper of the collections of the American Section of the Museum of the University of Pennsylvania, with whom he explored the cultures of the Southwest until her death in 1969. In 1973 he married Bonita ("Bonney") Freeman, a Ph.D. in folklore with a concentration in anthropology, who presently teaches at West Chester University in Pennsylvania. Together they raised two grandsons, Nathan and Levi, sons of Witthoft's own son, and they further renewed their parenthood by adopting two boys born in Guatemala in 1991 - Thomas Charles Jose and Richard Daniel Jorge. 
Bonney and John were active members of the West Chester Friends. John especially enjoyed being a member of the Indian Committee of the Philadelphia Yearly Meeting of the Religious Society of Friends; he was also superintendent of the Sunday School (First Day School), and worked with the Cub Scouts and Boy Scouts of the community.

John was a strong advocate and spokesman for the rights of the American Indian people; he tried particularly to help the Seneca in their resistance to the construction of Kinsua Dam on the Pennsylvania-New York border. He felt deeply shamed when the dam was built and the waters rose over Indian lands, and was too embarrassed to do fieldwork or even visit among the Iroquois until an invitation from them encouraged him to resume his friendships with Seneca people. He often said that some of the happiest times of his life were spent in the longhouse at Coldsprings and Six Nations in northern New York State.

At the time of his death from heart failure (following a bout with stomach cancer), Witthoft was pursuing symbolic systems of the Iroquois and was preparing a linguistic analysis of the Walam Olum, the disputed Lenape document "found" by Constantine Samuel Rafinesque, to show that it was composed by Rafinesque using Lenape texts readily available to him and not an original native record of mythological origins. John was also writing a book on Sir Walter Raleigh and the Age of Elizabeth, relating the exploration of the New World to subsequent treatment of Indians and Third World peoples.

A memorial service was held at West Chester Friends Meeting, with burial at the Birmingham Lafayette Cemetery, West Chester. John is survived by Bonney, their two grandsons and adopted sons, as well as by Witthoft's children, Tsani S. Witthoft, Jean S. Zeigler, and Maria S. Neve, a brother, a sister, six additional grandchildren, and two great-grandsons.

JOHN L. COTTER

Acknowledgments. I am indebted and most grateful to Bonita Freeman-Witthoft for biographical details of John Witthoft's life and for completing his bibliography. The photograph, courtesy University of Pennsylvania, The University Museum, shows John early in his teaching career, uncharacteristically posed with haircut, tie, and jacket "for the record."

\section{Bibliography of John Witthoft}

1946 Some Eastern Cherokee Bird Stories. Journal of the Washington Academy of Sciences $36: 177-180$.

The Cherokee Green Corn Medicine and the Green Corn Festival. Journal of the Washington Academy of Sciences 36:213-219.

Bird Lore of the Eastern Cherokee. Journal of the Washington Academy of Sciences 36:372-384.

The Grasshopper War in Lenape Land. Pennsylvania Archaeologist 16:91-94.

Smoothed-base Projectile Points from Eastern Pennsylvania. Pennsylvania Archaeologist 16:123-130.

Cayuga Midwinter Festival. New York Folklore Quarterly, Winter 1946-1947:24-39.

1947 An Early Cherokee Ethnobotanical Note. Journal of the Washington Academy of Sciences 37:73-75.

Notes on a Cherokee Migration Story. Journal of the Washington Academy of Sciences 37:304335.

Some Notable Life-histories in Zoological Folklore (with F. G. Speck). Journal of American Folklore 60:345-349.
1948 Will West Long, Cherokee Informant. American Anthropologist 50:355-359.

A Bucks County Argillite Cache. Pennsylvania Archaeologist 18:13-14.

1949 Green Corn Ceremonialism in the Eastern Woodlands. Occasional Contributions No. 13. Museum of Anthropology, University of Michigan, Ann Arbor.

An Outline of Pennsylvania Indian History. Pennsylvania History 16(3):2-15.

Stone Pipes of the Historic Cherokees. Southern Indian Studies 1:43-62.

A Jasper Cache from Chester County, Pennsylvania (with J. A. Mason). Pennsylvania Archaeologist 19:33-36.

The Cataloging of Archaeological Specimens Pennsylvania Archaeologist 19:61-63, 83 .

A Lancaster County Pictograph (with S. S. Farver). Pennsylvania Archaeologist 19:78-81.

1950 Frank Gouldsmith Speck, 1881-1950: Ethnologist and Teacher. Southern Indian Studies 2:1 39-44.

The History and Present Status of Pennsylvania Archaeology. Proceedings of the American Philosophical Society 94:301-307.

Notes on Pennsylvania Fluted Points. Pennsylvania Archaeologist 20(3-4):1-6.

1951 Bibliography of Frank Gouldsmith Speck. 
American Anthropologist 53:75-87.

The Pemberton Family Cemetery. Pennsylvania Archaeologist 21:21-32.

Historic Indian Caverns. Pennsylvania Archaeologist 21:33-35.

The Chewed Bullet. Pennsylvania Archaeologist 21:60-61.

Iroquois Archaeology at the Mid-century. Proceedings of the American Philosophical Society 95:311-321.

1952 Two Shenk's Ferry Sites in Lebanon County, Pennsylvania (with S. S. Farver). Pennsylvania Archaeologist 23:3-32.

Grooved Axes of Eastern Pennsylvania (with J. Miller). Pennsylvania Archaeologist 22:81-94.

A Paleo-Indian Site in Eastern Pennsylvania: An Early Hunting Culture. Proceedings of the American Philosophical Society 96:464-495. (Reprinted in 1971 in Foundations of Pennsylvania Prehistory, edited by B. C. Kent, I. F. Smith III, and C. McCann, pp. 13-64)

Comments on the Cultural Position of the Herriot Farm Site. West Virginia History 13:249-253.

1953 The American Indian as Hunter. Pennsylvania Game News 24(2):12-16. 24(3):16-22. 24(4):8-13. (Reprinted as Anthropology No. 6 , Pennsylvania Historical and Museum Commission, Harrisburg)

Broad Spearpoints and the Transitional Period Cultures in Pennsylvania. Pennsylvania Archaeologist 23:4-31. (Reprinted in Foundations of Pennsylvania Prehistory, edited by B. C. Kent, I. R. Smith III, and C. McCann, pp. 161-194.)

Micmac Pipes, Vase-shaped Pipes, and Calumets (with H. A. Schoff and C. F. Wray). Pennsylvania Archaeologist 23:89-107.

An Ohio Effigy Pipe. Ohio Archaeologist 3:10-11, 13.

The Grasshopper War Folktale. Journal of American Folklore 66:295-301.

1954 A Brief History of the Indian Hunter. Pennsylvania Game News 25(6):8-15. 25(7):39-40. 25(8):19-23. 25(9):41-46. (Reprinted as Anthropology No. 8, Pennsylvania Historical and Museum Commission, Harrisburg)

Pottery from the Stewart Site, Clinton County, Pennsylvania. Pennsylvania Archaeologist 24:22-29.

A Note on Fluted Point Relationships. American Antiquity 19:271-273.

1955 Worn Stone Tools from Southeastern Pennsylvania. Pennsylvania Archaeologist 25:16-31.

The Seventeenth Century Origins of the Shawnee (with W. A. Hunter). Ethnohistory 2:42-57.

1956 The Art of Flint Chipping. Ohio Archaeologist 6:136-142
The Art of Flint Chipping. Ohio Archaeologist 7:17-20, 35, 42-45, 80-88, 92.

An Ohio Artifact from Muncy. Now and Then 11:141-146. Muncy, Pennsylvania.

In Defense of Surface Hunting. Pennsylvania Archaeologist 26:5-14.

1957 Paperbacks, Monographs, and Digressions. Pennsylvania Archaeologist 27:5-22.

1958 Indian Methods of Skin Dressing and Tanning. Ohio Archaeologist 8:94-99.

Some Sources of Uncertainty in Radio-carbon Dating. Bulletin (New York State Archaeological Association) 12:1-4.

1959 Ancestry of the Susquehannocks. In Susquehannock Miscellany, edited by W. F. Kinsey and J. Witthoft, pp. 19-60. Pennsylvania Historical and Museum Commission, Harrisburg.

Susquehannock Shaft Polishers and the Indian Sundial. In Susquehannock Miscellany, pp. 120-125. Pennsylvania Historical and Museum Commission, Harrisburg.

Notes on the Archaic of the Appalachian Region. American Antiquity 25:79-85. (Reprinted in 1971 in Foundations of Pennsylvania Prehistory, edited by B. C. Kent, I. F. Smith III, and C. McCann, pp. 97-108.)

Notes on an Indian Burial from North-central Pennsylvania. Pennsylvania Archaeologist 29:40-48.

1960 Of Forgeries and Fantasies. Pennsylvania Archaeologist 30:1-17.

1961 Notes on the Archaic Cultures of the Appalachian Mountain Region. Bulletin (New York State Archaeological Association) 21:7-15.

1962 Comment. In The Paleo-Indian Tradition in Eastern North America, by R. J. Mason. Current Anthropology 3:267-270.

1963 General Interpretations. In The Townsend Site near Lewes, Delaware, by H. G. Geiger and T. D. Steward. Archeolog 15:59-69.

1965 Indian Prehistory of Pennsylvania. Pennsylvania Historical and Museum Commission, Harrisburg.

The Basic Problems of Archaeological Surveys. Journal of the Archaeological Society of Maryland 1:1-4.

An Introduction to the Prehistoric Culture Complexes of the United States. Wyoming Review 1:3:23-39. Wilkes-Barre, Pennsylvania.

1966 Cayuga Origin Myth. In The Great Tree and the Longhouse: The Culture of the Iroquois, by $\mathrm{H}$. W. Hertzberg, pp. 12-19. Macmillan, New York. Archaeology as a Key to the Colonial Fur Trade. Minnesota History 40(4):203-209.

A History of Gunflints. Pennsylvania Archaeologist 36:12-49.

Glazed Polish on Flint Tools. American Antiquity 32:383-388. 
1967 Petrographic Studies: Lateritic Flints. MASCA Newsletter 3(1):3-4. Museum Applied Science Center for Archaeology, Philadelphia.

Stone Spheres and Hammers. Maryland Archaeologist 2:4-10.

1968 Flint Arrowpoints from the Eskimo of Northwestern Alaska. Expedition 10(2):30-37.

1969 The Wyoming Expedition of 1968 (with F. Eyman). Expedition 11(2):22-25.

Metallurgy of the Tlingit, Dene, and Eskimo (with F. Eyman). Expedition 11(3):12-23.

1971 Pottery from the Stewart Site. In Foundations of Pennsylvania Prehistory, edited by B. C. Kent, I. F. Smith, and C. McCann, pp. 467-476. Pennsylvania Historical and Museum Commission, Harrisburg.

Two Shenk's Ferry Sites in Lebanon County, Pennsylvania (with S. S. Farver). In Foundations of Pennsylvania Prehistory, edited by B. C. Kent, I. F. Smith, and C. McCann, pp. 425-466. Pennsylvania Historical and Museum Commission, Harrisburg.

1972 Section on Beads of the G. W. Smith Collection. In Surface Archaeology of SW Washo County, Nevada: The G. W. Smith Collection, by C. M. Aikens. Desert Research Institute, Reno, Nevada.

1974 The Mechanics of Conchoidal Fracture: A Bibliographic Note. Newsletter of Lithic Technology 3:40-53. Pullman, Washington.

Bushwhackers and Melungeons: Indian Remnant Groups or Libels? Keystone Folklore 19: 183-205.

1975 Lenape Indian Fall Harvest (with B. Freeman-
Witthoft). Frontiers (fall issue):9-12. Philadelphia.

1976 Frank Gouldsmith Speck. Dictionary of American Biography. Supplement B. Scribner's Sons, New York.

1977 Ralph Linton. Dictionary of American Biography. Scribner's Sons, New York.

Cherokee Indian Use of Potherbs. Journal of Cherokee Studies 2:250-255. Cherokee, North Carolina.

1978 Robert Lowie. Dictionary of American Biography. Scribner's Sons, New York.

1979 Observations of Social Change Among the Eastern Cherokees. In The Cherokee Nation, a Troubled History, by D. H. King, pp. 202-222. University of Tennessee Press, Knoxville.

1981 Edith Hamilton. Dictionary of American Biography. Supplement 7. Scribner's Sons, New York.

1984 Comparison of Delaware and Susquehannock Settlement Patterns. In The Lenape Indian, A Symposium, edited by H. C. Kraft. Publication No. 7, Archaeological Research Center. Seton Hall University, South Orange, New Jersey.

1991 Frank Speck: The Formative Years. In The Life and Times of Frank G. Speck 1881-1950, edited by R. Blankenship, pp. 1-8. Publications in Anthropology No. 4. University of Pennsylvania, Philadelphia.

1992 The Lenape as Peacemakers of the Forests. Keystone Folklore 4(2):49-58.

1994 The Direct Historical Approach to Lenape Archaeology. Pennsylvania Archaeologist 64(1):64-69. 